\title{
All About the Giants: Probing the INFLUENCES ON GROWTH AND INCOME INEQUALITY AT THE END OF THE $20^{\mathrm{TH}}$ CENTURY
}

\author{
ALBERT BERRY \\ JOHN SERIEUX
}

CESIFO WORKING PAPER NO. 840

CATEgORY 5: Fiscal Policy, MaCROECONOMICS AND GROWTH

JANUARY 2003

PRESENTEd at CESifo CONFERENCE ON Globalisation, INEQUALITY AND WELL-BEING, NOVEMBER 2002

An electronic version of the paper may be downloaded

- from the SSRN website:

- from the CESifo website: www.CESifo.de 


\title{
All About the Giants: Probing THE INFLUENCES ON GROWTH AND INCOME INEQUALITY AT THE END OF THE $20^{\mathrm{TH}}$ CENTURY
}

\begin{abstract}
This paper presents estimates of world output growth from 1970 to 2000 , the distribution of income among countries and persons for the years 1980, 1990 and 2000, and world poverty rates for the same years. It also presents the results of a series of simulation exercises that attempt isolate the effect of particular country and regional experiences on world output growth and changes in global income inequality and poverty. The authors find that rapid growth in China (despite a downward adjustment of official growth estimates) had a powerful impact on the growth of world output in both the 1980s and 1990s, but that negative economic growth in Eastern Europe more than offset that effect in the 1990s. With respect to the distribution of income however, the equalizing effect of China's rapid growth, despite the contradictory impact of increasing domestic inequality, was dominant through both the 1980s and 1990s. Only India's influence remained substantial by comparison. Other identifiable events of the period, such as the economic contraction in Eastern Europe and continued economic decline in Africa had little statistical impact. Thus, when the combined influence of these two countries' above-average growth rates is removed, the improving global distribution of income suggested by all statistical measures becomes one of sharply worsening inequality. The impact of these twocountries is similarly critical with respect to global poverty reduction.
\end{abstract}

JEL Classification: F0, I3, O4.

\author{
Albert Berry \\ Department of Economics \\ University of Toronto \\ 1 Devonshire Place \\ Toronto, Ontario \\ Canada, M5S $3 K 7$
}

\author{
John Serieux \\ Department of Economics \\ University of North Carolina \\ Gardner Hall CB 3305 \\ Chapel Hill, NC 27599-3305 \\ USA \\ jserieux@email.unc.edu
}




\section{Introduction}

The third quarter of the 20th century was characterized by fast growth in many countries but also by sluggish and even negative growth in many others. ${ }^{1}$ The last two decades, in particular, have brought a wave of historic changes in several regions of the world and in the character of the world economy, and a variety of theories and pieces of factual information suggest that past distributional patterns might be changing. Theories of economic convergence, which have received much attention in recent years, tend to support the presumption that globalization, with its increasing economic integration among countries, will strengthen the forces of convergence and lower income inequality between countries (Barro, 1991; Barro and Sala-I-Martin, 1992; Ben-David, 1993). On the other hand, many countries have suffered significant increases in internal inequality over the last two decades, with some authors suggesting that this trend is causally related to globalization and market-friendly economic reforms (Wood, 1994; Robbins, 1996). Has this intra-country pattern of increasing inequality been strong enough to offset the effects of any impulse toward inter-country convergence, if indeed both of these effects can be shown to exist? More generally, what factors have been the key ones in determining the recent evolution of world inequality? This paper reviews the evidence on the former question but its main concern is the latter one.

With slower world economic growth since the 1970s, any serious increase in inequality might mean a derailment of the process of poverty reduction that had been fairly continuous over the post-war period. Concern on this point has been fuelled by two recent studies from the World Bank (Milanovic, 2002; Dikhanov and Ward, 2001), referring to the period 1988-1993, and reporting significant increases in inequality (of 3-4 percentage points in the Gini coefficient) over that period.

\footnotetext{
${ }^{1}$ The first two paragraphs draw on Berry and Serieux, 2002.
} 
If this result were accurate, and if the trend were to continue at anything close to the rate they estimate, the world would be in for an increase in inequality probably strong enough to imply an end to a long period of reduction in the incidence of poverty.

Such concerns notwithstanding, the weight of recent evidence points to relative stability in world inequality over the last half-century, and probably a modest decline in the last two decades. World income and consumption inequality rose dramatically during the period from 1820 (perhaps sooner but we know of no estimates prior to that year) until 1950 but, according to most of the more careful analyses, has not changed significantly over the last half century (Bourguignon and Morrisson, 2002; Berry et al, 1983; Berry and Serieux, 2002; Schultz, 1998; Bhalla, 2001). While there is some disagreement on the latter point, it can be mainly traced to methodological issues on which, in fact, most careful students do not disagree (e.g. the use of purchasing power parity in conversion among currencies, ${ }^{2}$ treatment of the individual person as the unit of analysis $)^{3}$; between country inequality, which has historically driven changes in world inequality, so measured, has thus been relatively constant over the period.

\footnotetext{
${ }^{2}$ UNCTAD was one of the institutions (along with UNDP, 1998) to report a major increase in inequality, with the Gini coefficient rising from 0.66 in 1965 to 0.74 in 1990 and the ratio of the richest quintile to the poorest rising dramatically from 31.1 to 60.1 (UNCTAD, 1997, 81). The report drew on Korzeniewicz and Moran (1997). The authors were aware that the choice between market exchange rate conversion and PPP conversion matters. They judged that the latter was the more appropriate way to gauge relative welfare conditions but followed Arrighi (1991) to the dubious conclusion that exchange rates provide a better "indicator of the command that different countries have over the human and natural resources."

${ }^{3}$ An exception is Milanovic, 2002, who makes the case for using exclusively data from household surveys in estimates of world inequality and reports a sharp increase in that inequality between 1988 and 1993. As discussed elsewhere (e.g. Berry and Serieux, 2002; Bhalla, 2001), the arguments for this approach do not appear to be persuasive. Household data, while providing the principal evidence on the level of inequality, have their own weaknesses and often suffer from lack of comparability over time. Other sources can thus be useful supplements, and when used judiciously, give a better overall picture than can household data alone.
} 
However, this general consensus of modest change seems, at first blush, to be at odds with the fact that the last decades of the twentieth century brought a wave of historic changes each of which could have been expected to result in substantial changes in the growth and distribution of world income. Prominent among these changes have been:

- the break-up of the Soviet bloc and the transition of its former members toward the market system;

- accelerated growth and an increasing role of the market in the Chinese economy;

- a long-awaited period of good growth in India;

- the first prolonged slump for the Japanese economy in the post-war period, suggesting that its period as the only fast-growing industrialised country has come to an end;

- the international debt crisis of the 1980s, that made this a "lost decade" in South and Central America;

- a severe regional crisis in Sub-Saharan Africa due not only to the extended crisis of heavily indebted poor countries (HIPCs) - most of which are in sub-Saharan Africa — but also with an underlying failure of agriculture to grow at a satisfactory rate, rapid population growth and, more recently, the traumatic incursion of AIDS;

- a general policy shift in nearly all countries towards a greater use of the market in resource allocation; and finally

- "globalisation"- the increasingly tight interaction among national economies, to the point where the economic raison d'être of the national state is increasingly called into question.

Have the effects of these phenomena been weaker than expected, or have they managed, more or less, to cancel out each other? Through a series of simulation exercises, we attempt to answer this question by measuring the magnitude and direction of their effects on world income (output) growth and its distribution. 


\section{Methodological and Data Issues}

Our estimates of regional and world growth rates are the output-weighted sums of individual country growth rates. These (average annual) country growth rates were estimated from constant price measures of output in local currency and then, to ensure comparability (in purchasing power values of output across countries) growth estimates were weighted by current international dollar (\$PPP) estimates of GDP at the beginning of each decade (i.e. 1970, 1980 and 1990). The PPP estimates are derived from the Penn World Tables (for 1970) and the World Bank (1980 and 1990).

Ensuring a reasonable and credible estimate of China's income levels and growth rates proved a particular challenge for this research. Reasonable accuracy is especially important in light of the size of that country, but the figures remain controversial for various reasons. Wu (1998), after examining official and alternative estimates, concluded that China's official figures underestimated output up until at least the late 1980s, and that the growth rate was overestimated by at least $2 \%$ since the late 1970s. Using this presumption and the range of alternative estimates provided by various authors (Keidel 1992; Maddison 1998; Ren 1997; Wu 1998), we recalculated China's output levels (in international dollars) for the 1979-2000 period based on an assumption of a $10 \%$ underestimate of (World Bank- reported) GDP (in domestic currency) in 1987, and a consistent overestimate of growth of $2.5 \%$. Fortunately, though these adjustments to the official data reduce the magnitude of China's influence on world economic growth, inequality and poverty, Berry and Serieux (2002; Appendix Table B2) found that, if the need for an adjustment is accepted, the final result is not overly sensitive to the degree of adjustment within the range suggested by various informed observers (i.e. plus or minus one percentage point in either direction from the growth estimates used here, or plus or minus 5 percentage points in either direction for the overall output estimates in 
1987). In effect, any combination of adjustments within the range suggested by the work of Keidel (1992), Wu (1998) and Maddison (1998), leads to similar overall results.

All distribution estimates are, of course, based on purchasing power parity estimates of country (and within-country income group) incomes. Intra-country inequality was taken into account in our estimates of the distribution of world income by dividing all medium and large countries (those with populations of over 25 million in 2000) into five, ten or forty income groups based on estimates of the distribution of gross income among persons for the relevant years (1980, 1990 and 2000). ${ }^{4}$ Thus the world of 163 countries (used for estimating inter-country inequality) was decomposed into one of 383 income groups, of which 255 were sub-national income groups with an identifiable range of income. ${ }^{5}$ These income groups accounted for $85 \%$ of the population of the countries represented and $81 \%$ of total world population in 2000 , with similar proportions for other years. Poverty estimates are based exclusively on the within-country income group data of the 35 medium and large countries and extrapolated to the rest of the world by assuming that, for a given level of per capita income, small country poverty rates are similar to large country rates. Though this is a strong assumption, given the dominance of medium-to-large countries in terms of world population (81\%), even a fairly radical departure from this assumption would have little statistical effect.

Given basic measures of output growth and income distribution, global counterfactuals were simulated by removing per capita output growth or population effects through an assumption of no

\footnotetext{
${ }^{4}$ China and India (by far the largest countries) were divided into 40 income groups, the United States and Indonesia (the next largest) were divided into 10 income groups (deciles) and all other countries with populations of 25 million or higher (except the DRC for which no distribution data was available) were divided in to 5 income groups (quintiles). ${ }^{5}$ This means, of course, that 128 small countries are still treated as single income groups, but sensitivity analyses indicate that, because together they represent only $15 \%$ of the total population, further subdivision of these countries (into income groups) would add little to the precision of the inequality estimates.
} 
change in per capita income or population across countries (which, for distribution measures, is identical to an assumption of identical growth rates across countries and income groups). The counterfactuals for country and region effect were simulated by assuming that these countries' per capita incomes or populations grew at the same rate as the remainder of the world did when these countries are removed from the sample, or their level of inequality did not change—in effect negating the influence that derives from a country or region's deviation from the world average or changes in its inequality. The difference between the actual measures and the resulting measures when these assumptions are made indicate the magnitude of the omitted effect on actual measures.

The issue of whether to fix overall incomes or per capita incomes was an interesting one. While the effect of holding total country or world incomes constant (or moving in concert with the rest of the world) has a more immediately interpretable distributional implication, this counterfactual contains an implicit assumption of independence between output and population growth that cannot be easily defended. Holding per capita income fixed, is free of such a bias and was thus the chosen option in most (though not all) cases. An increase in the income of any income group with above world average per capita income causes the Theil and Atkinson coefficients to unambiguously increase (implying worsening inequality) while an increase in the income of any income group with below world average income causes these measures to unambiguously decrease (implying improving inequality). The strengths of these effects depend, of course, on the size of these income groups and the distance from the world mean. ${ }^{6}$

\footnotetext{
${ }^{6}$ The effect on the Gini coefficient is much more difficult to determine but it is unlikely to be radically different.
} 


\section{The Pattern of Slowing World Growth}

The world economy grew at an average rate of $3.81 \%$ per year during the 1970 s, then $2.86 \%$ over the 1980 s, and $2.46 \%$ over the 1990 s (Table 1). Per capita growth fell from $1.94 \%$ to $1.16 \%$ to just $1.06 \%$ in the 1990s. This monotonic fall in growth over the three decades occurred both in the industrial countries and in the transitional countries, but developing countries experienced a rebound of growth in the 1990s after the poor performance of the 1980s. Sub-Saharan Africa remained the exception among developing regions, as it continued its negative per capita income growth through the 1990s.

Table 1

Average Annual Rate of Output Growth by Region and by Sub-Period (1970-2000) ${ }^{(\text {a) }}$

\begin{tabular}{|l|c|c|c|c|c|c|}
\hline \multirow{2}{*}{ REGION } & \multicolumn{5}{|c|}{ Weighted Country Averages $^{(\mathbf{b})}$} \\
\cline { 2 - 7 } & \multicolumn{3}{|c|}{ Real GDP } & \multicolumn{2}{c|}{ Real Per Capita GDP } \\
\cline { 2 - 7 } & $\mathbf{1 9 7 0 - 8 0}$ & $\mathbf{1 9 8 0 - 9 0}$ & $\mathbf{1 9 9 0 - 0 0}$ & $\mathbf{1 9 7 0 - 8 0}$ & $\mathbf{1 9 8 0 - 9 0}$ & $\mathbf{1 9 9 0 - 0 0}$ \\
\hline Sub-Saharan Africa & 3.16 & 1.97 & 2.01 & 0.29 & -0.96 & -0.62 \\
East Asia & 4.63 & 4.98 & 4.06 & 2.75 & 3.50 & 2.92 \\
\hline South Asia & 3.31 & 5.65 & 5.53 & 0.90 & 3.42 & 3.67 \\
\hline Central and South America & 5.56 & 1.24 & 3.11 & 3.21 & -0.77 & 1.44 \\
\hline Middle East & 6.04 & 2.21 & 3.38 & 3.19 & -0.79 & 1.35 \\
\hline Eastern Europe & 5.17 & 1.70 & -3.47 & 4.31 & 0.98 & -3.40 \\
\hline Western Europe & 2.99 & 2.48 & 2.06 & 2.38 & 1.97 & 1.57 \\
\hline North America & 3.16 & 2.55 & 3.15 & 1.73 & 1.34 & 1.84 \\
\hline Industrial Countries & 3.14 & 2.75 & 2.41 & 2.35 & 2.16 & 1.74 \\
\hline Transitional Economies & 5.17 & 1.70 & -3.41 & 4.31 & 0.98 & -3.40 \\
\hline Developing Countries & 4.75 & 3.59 & 4.63 & 2.47 & 1.53 & 2.94 \\
\hline WORLD & $\mathbf{3 . 8 1}$ & $\mathbf{2 . 8 6}$ & $\mathbf{2 . 4 6}$ & $\mathbf{1 . 9 4}$ & $\mathbf{1 . 1 6}$ & $\mathbf{1 . 0 6}$ \\
\hline Sources:
\end{tabular}

Sources: World Bank, World Development Indicators 2001 (Online); UN Common Database (Online).

A series of simulations designed to highlight the impact of what happened in terms of either population growth or per capita output (income) growth in selected regions reveals several key features of those decades (see Appendix Table A1): 
(a) The strong growth performances of China and India contributed importantly to overall world growth, especially in the 1990s. Had both just matched rest-of-the world economic growth, total world growth would have been slower by about half a percentage point per year in the 1990s (the effect was less in the 1980s) and per capita income growth would have been only half of what it actually was in the $1990 \mathrm{~s}(0.55 \%$ vs. $1.06 \%)$.

(b) Measured this way, Japan contributed positively to world growth in the $1980 \mathrm{~s}$ and negatively in the 1990s, but in both cases the effect was of modest proportions.

(c) The collapse of Eastern Europe had a dramatic negative effect in the 1990s--lowering world growth from the $3.02 \%$ it would have been had this region matched the rest of world average to its actual $2.46 \%$, and cutting per capita growth from $1.61 \%$ to $1.06 \%$. The impact of the region's weak performance in the 1980s was in the same direction but much smaller, since at that time the regional economy was stagnating rather than shrinking.

(d) Some, but not a great deal, of the growth decline in the 1980 s vis à vis the 1970 s was due to the downturn in South and Central America.

(e) Africa's slow per capita income growth pulled the world average down in both decades but only by a small amount due to its small share of world income and modest share of world population.

Table A1 also reveals the effect of differences in the rates of population growth across countries. These effects are much smaller than those of differences in per capita income growth. Thus even for China, famous for its slow population growth due to a draconian policy designed to achieve that goal, the estimated impact on world per capita income growth of that slow population growth was to raise the world average from the $0.90 \%$ per year it would have been had China's population growth been the same as the world's to the actual $1.06 \%$ per year. The impact of India's above average population growth was to lower world per capita growth from the $1.14 \%$ it would have been had India's record matched the world's to the actual $1.06 \%$. Whereas the impact of the income 
performance of these two countries together was, as noted, highly significant, the population effects tended to cancel out since India's population growth was above average and China's below average.

\section{Factors in Changing World Income Inequality}

World income inequality is extremely high, and although it does not appear to have been rising (by most of the more interesting definitions and calculations) for the last few decades, the degree of inequality constitutes good reason to better understand the factors that contribute to it. Trends in world inequality over the last couple of decades or so are likely to have been influenced by a wide range of factors, that may have been mutually offsetting — some tending to lower inequality, others to raise it. The presence of these latter factors is another reason to worry about getting a better understanding, since they could eventually dominate the benign ones. In short, it is of interest to identify and quantify several of the major factors at work and to thus disaggregate the overall trends.

Inter-country inequality (i.e. that element of the inequality of world distribution among individuals which reflects differences in average incomes across countries but not the inequality within countries--which is introduced in the next section) changes in response to differences in either or both of the income growth rate across countries and the population growth rate across countries. When all countries record the same performance on both of these growth rates, then the intercountry distribution of world income does not change. Assuming that both population and income per capita growth rates are positive, the whole system is thus expanding, but each country's share of world income and population stays the same over time. 
How do differences in these growth rates across countries affect the inter-country distribution of world income? When, with no differences in the rate of population growth across countries, richer countries register slower (faster) income growth, world inequality unambiguously improves (worsens), since the income share of the top countries is falling (rising) while their population share stays the same. When population growth is slower in the richer countries (as it usually is) the effect of this factor is, however, ambiguous. It implies that per capita income is rising faster in those countries. Thus a country at the top of the world income distribution which started with $5 \%$ of world population and $20 \%$ of world income would, after a period during which its income growth was the same as in other countries but its population growth was slower, have the same $20 \%$ of world income but, say, $4 \%$ of world population. Though, on the surface, this may appear to imply a worsening, whether it is or is not will depend on the nature of the reconfiguration taking place at lower income levels due to varying rates of population growth.

Clearly, if population is growing faster in the poorer countries, their total national incomes must be rising faster in order for world income distribution not to worsen. If their income growth exceeds that of richer countries by the same amount as their population growth, then per capita incomes are rising at the same rate in all countries, and any changes in world distribution have to do with the fact that the population shares of the different countries are changing. In this case, the direction of change in world income cannot be easily predetermined because it depends on the original population shares, the rate of growth of these shares, and the position of the fastest and slowest growing countries. The effect is least ambiguous for countries in the middle of the distribution because any increase in that group's share of world income will reduce inequality by reducing the 
relative importance of extremes (i.e. a thinner tailed distribution), whereas any reduction in their share of world income will do the opposite.

How have actual differences in income and population growth rates affected the evolution of world income inequality over the last two decades? Together, these two forces at play have, as seen in Table 2, produced a decline in the inter-country inequality Gini coefficient of about 3 percentage points $(0.585$ to 0.553$)$.

TABLE 2

Separating the effects of world population and income growth on the inter-country distribution of income

\begin{tabular}{|c|c|c|c|c|c|c|c|c|c|c|}
\hline & $\begin{array}{c}\text { Population } \\
\text { Year }\end{array}$ & $\begin{array}{c}\text { Income } \\
\text { Year }\end{array}$ & GINI & $\begin{array}{l}\text { Diff. } \\
\text { From } \\
\text { Actual }\end{array}$ & THEIL & $\begin{array}{l}\text { Diff. } \\
\text { From } \\
\text { Actual }\end{array}$ & ATK. (0.5) & ATK. (1) & $\begin{array}{l}\text { Diff. } \\
\text { From } \\
\text { Actual }\end{array}$ & ATK. (2) \\
\hline \multirow{3}{*}{ Actual } & 1980 & 1980 & 0.585 & & 0.700 & & 0.288 & 0.503 & & 0.695 \\
\hline & 1990 & 1990 & 0.578 & & 0.636 & & 0.275 & 0.471 & & 0.654 \\
\hline & 2000 & 2000 & 0.553 & & 0.559 & & 0.251 & 0.428 & & 0.623 \\
\hline \multirow{3}{*}{$\begin{array}{l}\text { Fixed Total } \\
\text { Income } \\
\text { Differentials } \\
\end{array}$} & 1990 & 1980 & 0.608 & 0.030 & 0.756 & 0.120 & 0.311 & 0.530 & 0.060 & 0.712 \\
\hline & 2000 & 1990 & 0.597 & 0.044 & 0.687 & 0.128 & 0.295 & 0.497 & 0.069 & 0.679 \\
\hline & 2000 & 1980 & 0.625 & 0.072 & 0.807 & 0.247 & 0.331 & 0.554 & 0.125 & 0.728 \\
\hline \multirow{3}{*}{$\begin{array}{l}\text { Assuming fixed per } \\
\text { capita income } \\
\text { differentials }\end{array}$} & 1990 & 1980 & 0.590 & 0.012 & 0.695 & 0.059 & 0.290 & 0.501 & 0.030 & 0.685 \\
\hline & 2000 & 1990 & 0.581 & 0.029 & 0.637 & 0.077 & 0.278 & 0.471 & 0.043 & 0.650 \\
\hline & 2000 & 1980 & 0.595 & 0.042 & 0.693 & 0.134 & 0.293 & 0.500 & 0.072 & 0.679 \\
\hline \multirow{3}{*}{$\begin{array}{l}\text { Assuming fixed } \\
\text { population } \\
\text { differentials }\end{array}$} & 1980 & 1990 & 0.554 & 0.023 & 0.581 & -0.055 & 0.252 & 0.441 & -0.030 & 0.629 \\
\hline & 1990 & 2000 & 0.535 & 0.018 & 0.514 & -0.045 & 0.234 & 0.402 & -0.026 & 0.588 \\
\hline & 1980 & 2000 & 0.512 & $0.040^{-}$ & 0.465 & -0.094 & 0.213 & 0.372 & -0.056 & 0.553 \\
\hline
\end{tabular}

Differences in population growth, with total incomes held constant in each country at 1980 levels $^{7}$, had two effects: one to push per capita income down faster in countries with fast growing population, most of which are now in Africa and the Middle East, which would on balance tend to

\footnotetext{
${ }^{7}$ This counterfactual experiment of holding total income constant in each country is the same, in terms of its impact on how distribution changes, as assuming the same positive or negative growth rate of income for all countries.
} 
increase world inequality, and secondly to increase the population share of those same countries, with the same broad effect. This counterfactual experiment, in which we let the differences in population growth have their impact in the absence of any changes in total income, produces a Gini coefficient of 0.625 by the year 2000 , and can be read as indicating that population growth differentials by themselves created an upward pressure on the Gini corresponding to four percentage points over those two decades (from 0.585 to 0.625 ). ${ }^{8}$ Since, in fact, the Gini fell by three points, the implication is that the impact of differences in rates of income growth (population held constant) were responsible for a remarkable downward pressure of about 7 percentage points (the difference between 0.625 and 0.553 ). This is basically the result of the fast income growth in the two large low-income countries, China and India. ${ }^{9}$ Similar patterns emerge when one looks at the other measures of inter-country inequality. All show a decline over these two decades, with population growth differentials pushing inequality up but growth rate differentials more than offsetting them.

Since it is widely presumed that population growth does have some positive impact on income growth, the above disaggregation may not be the most interesting as one tries to understand the combination of direct and indirect effects of differences in that variable across countries. It is thus interesting to ask what impact population growth differentials would have had if per capita income

\footnotetext{
${ }^{8}$ A considerable part of this upward impact on world inequality is due to the fact that when one holds total income growth constant, the countries with fast population growth become automatically the ones with worst per capita income growth. Since most cases of fast population growth are low-income countries, their worse-than-average trends in per capita income growth in the simulation exercise produce much of this upward effect on world inequality. Some, however, as noted below, is simply due to the changing relative weights of countries when population grows at different rates.

${ }^{9}$ The separate impacts of the differences in income growth and in population growth can be read off differently. If one asks what would have happened in the absence of any population changes, i.e. with only the actually observed income changes at the country level, the answer is that the Gini coefficient would have fallen from 0.585 to 0.512 , the same downward effect of over 7 percentage points as noted above. By the same token, the population growth differences could then be taken as explaining why the final observed Gini was 0.553 instead of 0.512 , i.e. as accounting for an upward impact on the Gini of a bit over 4 points.
} 
rather than total income were held constant in each country. This is equivalent to assuming (i.e. is based on the implicit assumption) that population growth raises total income in the same percent, so that the population effect being isolated is just the one that changes the relative weights of each country in the world population. As the middle rows of Table 2 reveal, the population growth differences are now seen as responsible for an upward effect on the world Gini of just one percentage point, considerably less than before (change from 0.585 to 0.595 ). To the differences in per capita income growth can then be attributed the gap between 0.595 and the actually observed 0.553 - a still striking 4.2 percentage points.

As noted in Barry and Serieux (2002), and reiterated later in this paper, all of the improvement in the distribution of inter-country (and, as we shall se, inter-personal) income can be attributed to the strong influence of China and India who, together, account of more than a third of world population. To dampen the effect of their population weights on our distribution estimates (and thus to ferret out the more general pattern) we re-estimated the inequality measures using the square roots of population estimates rather than actual population estimates. This has the effect of reducing the relative weights of very large countries. ${ }^{10}$ The modified inequality coefficients are presented in Table 3 below. The effect of this modification is to reverse the pattern of change, suggesting a worsening of the distribution of world (inter-country) income between 1980 and 1990 and 1990 to 2000 (and therefore across the two decades as a whole). That worsening was also consistent across all distribution estimates, a further confirmation that the influences that caused this worsening were generalized to all country income levels. ${ }^{11}$

\footnotetext{
${ }^{10}$ Tony Atkinson suggested this approach and, therefore, deserves the credit for this insight.
} 
TABLE 3

Estimates of world inter-country income inequality when population weights are the square the square roots of actual populations.

\begin{tabular}{|c|c|c|c|c|c|}
\hline YEAR & GINI & THEIL & $\begin{array}{c}\text { ATKINSON } \\
\mathbf{( 0 . 5 )}\end{array}$ & $\begin{array}{c}\text { ATKINSON } \\
\mathbf{( 1 )}\end{array}$ & $\begin{array}{c}\text { ATKINSON } \\
\mathbf{( 2 )}\end{array}$ \\
\hline $\mathbf{1 9 8 0}$ & 0.614 & 0.805 & 0.314 & 0.553 & 0.814 \\
\hline $\mathbf{1 9 9 0}$ & 0.620 & 0.845 & 0.324 & 0.570 & 0.827 \\
\hline $\mathbf{2 0 0 0}$ & 0.625 & 0.894 & 0.334 & 0.591 & 0.846 \\
\hline
\end{tabular}

It is also relevant to ascertain whether the distinction between effects of differing population growth and those of differing income growth depended greatly on their presence of combined influences of China and India. Appendix Table A2 replicates the simulations of Table 2 but excluding China and India. Note that, whereas this inter-country component of world inequality fell (0.585 to 0.553$)$ with all countries included, when these two are excluded it rises dramatically from 0.473 to 0.541 . This turnaround from the exclusion of China and India confirms the results from Table 3 that the distributional improvement that did occur was more than fully attributable to their influence. In their absence, the adverse effect of differing population growth was more dramatic, a full 6.6 percentage points (compared to 4 points for the world as a whole). The effect of differences in income growth-a major downward impact on inequality of about 7 percentage points when all countries are included — is now essentially absent. The exclusion of China and India when we analyse the impacts of differences in per capita income growth along with changes population shares suggest that they now have deleterious effects of similar magnitudes on the distribution of income. They both cause the Gini coefficient to rise by 3.4 percentage points ( 0.473 to 0.507 to 0.541$)$.

\footnotetext{
${ }^{11}$ The modification also causes the estimates of world inter-country income inequality to rise because per capita incomes become more dispersed.
} 
The effect of specific countries on how world inequality has played itself out can be addressed partly by seeing how the results change when those countries are simply excluded, as in the previous discussion based on A2. Alternatively, one can assume that the country's GDP or population, or both, grew at the average level for the rest of the world. This distinct conceptual experiment was applied in the analysis of factors underlying world growth, based on the figures of Table A1, and is repeated for the inter-country distribution of income in Table 4.

\section{TABLE 4}

Simulations of the inter-country distribution of world income (1990 and 2000) without Chinese, Indian and Eastern European per capita income growth effects

\begin{tabular}{|c|c|c|c|c|c|c|c|c|c|c|}
\hline & From & To & GINI & Diff. & THEIL & Diff. & ATK. (0.5) & ATK. (1) & Diff. & ATK. (2) \\
\hline \multirow{3}{*}{ Actual } & & 1980 & 0.585 & & 0.700 & & 0.288 & 0.503 & & 0.695 \\
\hline & & 1990 & 0.578 & & 0.636 & & 0.275 & 0.471 & & 0.654 \\
\hline & & 2000 & 0.553 & & 0.559 & & 0.251 & 0.428 & & 0.623 \\
\hline \multirow{3}{*}{$\begin{array}{l}\text { China grows at } \\
\text { rest-of-the-world } \\
\text { rate }\end{array}$} & 1980 & 1990 & 0.601 & 0.023 & 0.708 & 0.072 & 0.297 & 0.507 & 0.037 & 0.693 \\
\hline & 1990 & 2000 & 0.586 & 0.033 & 0.641 & 0.082 & 0.281 & 0.473 & 0.045 & 0.656 \\
\hline & 1980 & 2000 & 0.608 & 0.056 & 0.711 & 0.152 & 0.302 & 0.509 & 0.081 & 0.694 \\
\hline \multirow{3}{*}{$\begin{array}{l}\text { India grows at } \\
\text { rest-of-the-world } \\
\text { rate }\end{array}$} & 1980 & 1990 & 0.589 & 0.011 & 0.668 & 0.032 & 0.285 & 0.487 & 0.017 & 0.672 \\
\hline & 1990 & 2000 & 0.568 & 0.015 & 0.595 & 0.036 & 0.263 & 0.448 & 0.020 & 0.641 \\
\hline & 1980 & 2000 & 0.579 & 0.027 & 0.628 & 0.069 & 0.273 & 0.467 & 0.038 & 0.662 \\
\hline \multirow{3}{*}{$\begin{array}{l}\text { Both China and } \\
\text { India grow at } \\
\text { rest-of-the-world } \\
\text { rate }\end{array}$} & 1980 & 1990 & 0.609 & 0.031 & 0.743 & 0.107 & 0.308 & 0.524 & 0.054 & 0.708 \\
\hline & 1990 & 2000 & 0.599 & 0.046 & 0.683 & 0.124 & 0.296 & 0.495 & 0.067 & 0.673 \\
\hline & 1980 & 2000 & 0.630 & 0.077 & 0.790 & 0.231 & 0.328 & 0.546 & 0.118 & 0.722 \\
\hline \multirow{3}{*}{$\begin{array}{l}\text { Eastern Europe } \\
\text { grows at rest-of- } \\
\text { the-world rate }\end{array}$} & 1980 & 1990 & 0.578 & 0.000 & 0.636 & 0.000 & 0.275 & 0.470 & 0.000 & 0.655 \\
\hline & 1990 & 2000 & 0.551 & -0.001 & 0.560 & 0.001 & 0.248 & 0.429 & 0.001 & 0.630 \\
\hline & 1980 & 2000 & 0.551 & -0.001 & 0.560 & 0.001 & 0.248 & 0.429 & 0.001 & 0.630 \\
\hline
\end{tabular}

Not surprisingly, when China grows at the rest-of-the-world rate, all the distribution measures, except the Atkinson (2), indicate a worsening of the distribution of income. Even the Atkinson (2), which is extremely sensitive to changes near the bottom of the distribution, and therefore most responsive to India's improving fortunes, registers only very marginal improvements over both decades. The absence of India's per capita growth effect is not sufficient to cause a reversal of the improving trend in the distribution of world income but it weakens it considerably and even causes 
the Gini coefficient to suggest a worsening over the 1980s. Of course, forcing both China and India to grow at rest-of-the-world rates simply exacerbates the trend reversal that the absence of China's growth effect alone can accomplish. The counterfactual for Eastern Europe, however, leads to much less dramatic results. With Eastern Europe growing at rest-of-the world rates, the distribution of income between 1980 and 1990 is unaffected according to most measures, and the improvement between 1990 and 2000 and 1980 and 2000 are both only marginally better.

However, as suggested by Appendix Table A3, the powerful effect of Chinese and Indian per capita income growth on the distribution of world income is not similarly repeated with respect to their population growth differentials. Though assuming rest-of-the-world population growth for these countries and regions do have some effect on the changes in inter-country income inequality, neither of them have a significant effect on the trend of improving inequality, and their combined (and opposite) effects nearly cancel out.

\section{Allowing for Changes in Intra-Country Inequality}

The level and changes in world inequality reflect not only demographic developments and changes in the relative average incomes of the various countries but also changes in intra-country inequality. Though intra-country inequality can be very high indeed, decomposition exercises reveal that it is a much less important source of world inequality among persons or families than are the differences in average incomes across countries; the latter explain about $70-80 \%$ of all inequality reflected in the Theil index (Berry and Serieux, 2002, Table 5). In any case, it is necessary to take account of intra-country inequality and how it changes in order to have the full picture. 
Table 5, below, takes advantage of the decomposable nature of the Theil index to indicate which countries account for the bulk of the world's within-country inequality. It indicates that China and India make by far the biggest contributions to world (intra-country) inequality as measured by the Theil coefficient. However, while India has always been the largest contributor to total (intracountry) inequality, over the last two decades, the worsening distribution of income in China has resulted in a $34 \%$ increase in its contribution to world intra-country inequality. In the process, it has caught up to India in terms of relative contribution to total intra-country inequality. Countries such as Brazil, South Africa, and Nigeria with their extreme levels of inequality, contribute to total inequality in amounts far out of proportion to their share of world population while Germany and Japan, despite their relative size, remain minor contributors. The United States, though experiencing increasing inequality throughout the period, contributed less to total intra-country inequality in 2000 than it did in 1980 because its influence was overshadowed by the worsening distributions in countries such as China, the Russian Federation and Nigeria.

Table A4 summarizes a number of simulation experiments, again using overall inequality, not just the inter-country component of it. The per capita income growth differentials now have a downward impact of 0.021 on the Gini coefficient, while the population growth differentials have an upward effect of 0.032 . These numbers may be compared with those of Table 2, which involve the same experiments but take account only of the inter-country inequality. In that case, the per capita growth differentials had a downward effect of 0.042 and the population growth differentials an upward effect of 0.041 . On the income side the smaller per capita income effect may be due to the general trend towards increasing intra-country inequality over the period, which counteracts the general convergence in country per capita incomes. 


\section{TABLE 5}

Theil decomposition, indicating the contribution of major economies, and other large contributors, to total world intra-country inequality

\begin{tabular}{|c|c|c|c|c|c|c|c|c|c|c|}
\hline \multirow[t]{2}{*}{ Country } & \multicolumn{3}{|c|}{ Theil coefficient estimates } & \multirow[t]{2}{*}{$\begin{array}{l}\text { Estimate are } \\
\text { based on }\end{array}$} & \multicolumn{3}{|c|}{$\begin{array}{l}\% \text { of total medium and large } \\
\text { country inequality }\end{array}$} & \multicolumn{3}{|c|}{$\begin{array}{l}\text { Estimated \% of total (world) intra } \\
\text { country inequality }\end{array}$} \\
\hline & 1980 & 1990 & 2000 & & 1980 & 1990 & 2000 & 1980 & 1990 & 2000 \\
\hline Brazil & 0.530 & 0.636 & 0.580 & quintiles & 7.9 & 8.9 & 7.0 & 6.7 & 7.6 & 5.9 \\
\hline China & 0.150 & 0.194 & 0.271 & forty groups & 18.1 & 20.9 & 24.2 & 15.4 & 17.8 & 20.6 \\
\hline Germany & 0.112 & 0.114 & 0.133 & quintiles & 1.1 & 0.9 & 0.8 & 0.9 & 0.7 & 0.7 \\
\hline India & 0.292 & 0.274 & 0.336 & forty groups & 24.7 & 22.1 & 24.2 & 21.0 & 18.8 & 20.6 \\
\hline Indonesia & 0.240 & 0.195 & 0.195 & deciles & 4.4 & 3.3 & 2.9 & 3.7 & 2.8 & 2.5 \\
\hline Japan & 0.142 & 0.153 & 0.171 & quintiles & 2.0 & 1.8 & 1.5 & 1.7 & 1.5 & 1.3 \\
\hline Nigeria & 0.231 & 0.401 & 0.447 & quintiles & 2.0 & 3.7 & 4.0 & 1.7 & 3.1 & 3.4 \\
\hline Russian Federation & 0.090 & 0.112 & 0.209 & quintiles & 1.5 & 1.6 & 2.2 & 1.3 & 1.3 & 1.8 \\
\hline South Africa & 0.677 & 0.646 & 0.700 & quintiles & 2.3 & 2.2 & 2.1 & 2.0 & 1.8 & 1.8 \\
\hline United States & 0.232 & 0.266 & 0.282 & deciles & 6.5 & 6.3 & 5.6 & 5.5 & 5.4 & 4.8 \\
\hline
\end{tabular}

Note: Country estimates of the Theil coefficient are derived from estimates of income distribution among persons for the respective years. Total medium and large country intra-country inequality is the population-weighted sum of the individual country Theil coefficients ( 35 countries with populations over 25 million). The estimated world intra-country inequality is an extrapolation of the medium and large country estimate based and the assumption that intra country inequality in the small countries (15\% of world population) is roughly the same as it is in medium and large countries. 
By itself the impact of (changing) Chinese inequality has an upward effect of 0.007 , modest compared to other effects but reflecting a substantial increase in inequality of a country moving closer to the middle of the world income distribution. Meanwhile the impact of Chinese per capita income growth was downward by 0.038 and that of Chinese population growth downward by 0.003 . When all three Chinese effects are taken together, their downward impact was of 0.041 —equal in magnitude to the effect of global population growth differentials.

These counterfactual experiments find a negligible impact of the worsening U.S., Eastern European and Indian inequality. In fact, for no region tested do the changes in internal distribution have a really measurable impact on world inequality. Over the two decades together, only Chinese inequality had an impact of more than 0.001 on the Gini coefficient. The same pattern seems to hold for the Theil coefficient (though, as expected, the absolute changes are larger). The poor economic performances of Japan, Eastern Europe and Africa had larger, but still modest effects, and small in comparison to the effects of even India and especially China.

Table A5-1 to A8-2 presents the decile distribution of world income (including intra-country inequality effects) and how different it would have been had various countries or regions grown at world average rates over the 1980s and 1990s, rather than at the rates they actually grew. One convenient indicator is the ratio of average income of the top decile to that of the bottom decile. Consistent with the fact that overall inequality fell during this period, that ratio dropped from 73.7 in 1980 to 69 in 1990, and to 66.7 in 2000 . China's very fast growth contributed hugely to the decline in this ratio in the 1980s since, if China's growth had been just at the world average, the ratio would have risen to 78.7 instead of falling to 69-a difference of 9 (Table A5-1). Over the next decade, 
China's fast growth made a similar difference; in 2000, the gap between actual (66.7) and counterfactual (75.1) was 8.4. The slight decline is due largely to the fact that, though China's growth was even more above the world average in this decade than in the 1980s, its position in the world income distribution had shifted up considerably, with the result that its fast growth was now doing less to raise the income of the bottom decile. Whereas the income share of that bottom decile rose by 0.07 in the 1980s (Table A5-2), it only rose by 0.03 in the 1990s (Table A6-2). On the other hand, the share of the top decile also grew considerably more rapidly in the 1980s (2.08 percentage points) than in the 1990s (0.64 points)--see Table A5-2 and A6-2.

Taken by itself, the impact of India's growth was similar to that of China, both in direction and, rather surprisingly, only modestly less in degree. Like China's, this impact was slightly stronger in the 1980s (5.9) than in the 1990s (5.5), in spite of the fact that India's growth performance was better in the 1990s. This was due to the fact that, during the 1980s, India's distribution showed a net improvement, but in the 1990s the opposite occurred, so that the two factors were both at play during the 1980s to contribute to improved world distribution while in the 1990s they operated in opposite directions.

As expected Sub-Saharan Africa's weak growth contributed to keeping world inequality high; had its growth been average, then the ratio would have fallen to 63.9 instead of just to 69 in 1990 , and on to 64 instead of to 66.7 in 2000 . Finally, and as might be expected, the performance of South and Central America had only a modest impact on world inequality, since it tends to lie near the middle of the world distribution. In the 1980s, its very slow growth had a slightly inequality-reducing impact. In the 1990s, its growth was closer to the world average so the region's impact was 
minimal. The East European crisis had an even smaller effect, again because incomes are not too far from the world average.

\section{Factors in the 1980s and 1990s Poverty Trends}

The influence of the growth rates of key countries like China and India is most apparent in the trajectory of world poverty. Based on a $\$ 500$ poverty line (international dollars of 1985), world poverty incidence fell from 25.7 in 1980 to 14.6 in 1990, and to 12.1 in 2000 (Table 6). ${ }^{12}$ Advance was thus much slower in the 1990s than in the 1980s. (Using higher poverty lines like $\$ 1000$, the pattern of decline was different, with a larger drop in the 1990s than in the 1980s.) Poverty fell very rapidly in China and impressively in India as well, while rising in Africa.

Table A7 permits an assessment of the impact of these three regions on poverty decline, disaggregated into a population growth effect, a per capita income growth effect and an income distribution effect. For China, the impact of its income growth on poverty was very positive-downward effects of about 5.9 percentage points in 1990 and 3.9 in 2000 (for the $\$ 500$ poverty line). Slow population growth contributed in the same direction in 1990 while the increase in inequality worked in the other direction. Overall, developments in China accounted for about half of the large 11 percentage point decrease in poverty incidence over the 1980s but it contributed only moderately to the (much slower) rate of incidence decline in the 1990s because it was no longer the case that enough Chinese were in extreme poverty (under \$500) for the continued fast growth to

\footnotetext{
${ }^{12}$ While out poverty lines are not identical to the often-sighted ones of the World Bank ( $\$ 1$ a day etc.), it is quite obvious that our estimates suggest lower poverty rates. This can be attributed to two factors. First, our estimates are based on income estimates from national accounts, while theirs are based on alternative consumption estimates that are generally lower (implying higher poverty rates given comparable poverty lines). Second, their estimates of consumption growth are lower than our estimates of income growth, creating lower rates of poverty reduction. However, neither of these
} 
pull many more people out of it. But it did have a stronger impact with respect to the under $\$ 1000$ poverty line in the 1990s. India's impact was generally similar to that of China. Africa's overall effect, meanwhile, was quite small in spite of the region's weak performance. Even though poverty has been increasing in that region (Table 6), its population share is not large enough to impinge dramatically on these world trends when compared to the effects of China, India and other South Asian countries.

TABLE 6

Estimated Poverty Rates in Medium and Large Countries (85\% of total world population)

\begin{tabular}{|c|c|c|c|}
\hline $\begin{array}{l}\text { POVERTY LINES } \\
\text { (in \$PPP) }\end{array}$ & 1980 & 1990 & 2000 \\
\hline & \multicolumn{3}{|c|}{ ALL MEDIUM AND LARGE COUNTRIES } \\
\hline$<\$ 500$ & 25.7 & 14.6 & 12.1 \\
\hline$<\$ 1000$ & 53.8 & 43.6 & 28.5 \\
\hline \multirow[t]{2}{*}{$<\$ 1500$} & 60.5 & 54.1 & 44.8 \\
\hline & \multicolumn{3}{|c|}{ CHINA } \\
\hline$<\$ 500$ & 45.0 & 20 & 10.0 \\
\hline$<\$ 1000$ & 90.0 & 65.0 & 32.5 \\
\hline \multirow[t]{2}{*}{$<\$ 1500$} & 97.5 & 77.5 & 52.5 \\
\hline & \multicolumn{3}{|c|}{ INDIA } \\
\hline$<\$ 500$ & 37.5 & 22.5 & 20 \\
\hline$<\$ 1000$ & 80.0 & 67.5 & 45 \\
\hline \multirow[t]{2}{*}{$<\$ 1500$} & 87.5 & 82.5 & 70 \\
\hline & \multicolumn{3}{|c|}{ SUB-SAHARAN AFRICA } \\
\hline$<\$ 500$ & 56.9 & 57.5 & 66.5 \\
\hline$<\$ 1000$ & 74.8 & 75.3 & 71.4 \\
\hline \multirow[t]{2}{*}{$<\$ 1500$} & 85.2 & 85.8 & 80.8 \\
\hline & \multicolumn{3}{|c|}{ OTHER MEDIUM AND LARGE COUNTRIES } \\
\hline$<\$ 500$ & 7.8 & 3.6 & 3.0 \\
\hline$<\$ 1000$ & 22.1 & 18.7 & 13.7 \\
\hline$<\$ 1500$ & 27.8 & 26.3 & 25.1 \\
\hline
\end{tabular}




\section{Conclusions}

The rate of growth of world output decelerated from an annual average rate of $3.81 \%$ in the 1970 s to $2.86 \%$ in the $1980 \mathrm{~s}$ and $2.46 \%$ in the $1990 \mathrm{~s}$. Per capita income followed a similar pattern. However, both the inter-country and overall inter-personal distribution of world income improved between 1980 and 1990 and 1990 and 2000. This occurred because the distribution worsening effects of faster population growth in poorer countries and increasing intra-country inequality in a majority of countries were more than offset by faster per capita income growth near the bottom of the distribution (mostly that of China and India). Thus, despite the slower output growth, poverty rates continued to fall through the 1980s and 1990s, though with differing patterns.

At first blush, it would appear that there are a large number of factors, both national and regional, that have the potential to explain significant elements of this overall pattern of growth, income distribution and poverty reduction. Most prominent among these are the growth of the two major low-income countries (China and India), the economic stagnation of most of Sub-Saharan Africa, the near economic implosion in Eastern Europe and Central Asian in the 1990s, the negative per capita growth in Central and South America in the 1980s and the slow growth of Japan in the 1990s. Yet, as it turns out, only a few of these phenomena had statistically discernable effects on overall patterns of distributional change.

The examination of counterfactual that isolate these effects clearly indicate that the rapid growth of China, had a strong positive impact on world output growth and, despite the dampening effect of worsening income inequality within the country, explained nearly all of the improvement in the distribution of world income (both between countries and persons) and more than half of the 
poverty reduction. India's brisk growth during that period had similar, though more modest, effects. In fact, in the absence of the influences of China and India the pattern of improvement in inequality and poverty reduction would instead have been one of worsening and the deceleration in world output growth would have been even more dramatic.

Of the other influences, Eastern Europe's negative output growth in the 1990s was the single most powerful (and negative) influence on world output growth in the 1990s, but that experience had a barely discernable influence on the distribution of world income. All the other influences identified and isolated, including, most surprisingly, the negative growth in Sub-Saharan Africa, had either marginal or imperceptible influences on the patterns described above. Thus, with respect to the overall pattern of world income inequality and poverty reduction in particular, the story has been largely written by China and India. Their combined influence overshadows more worrying patterns in other countries and regions of the world. 


\section{References}

Arrighi, G, “ World Income Inequalities and the Future of Socialism”, The New Left Review 189 (September 1991), 39-65.

Barro, Robert, "Economic growth in a cross section of countries", Quarterly Journal of Economics 106 (May 1991), 407- 463.

Barro, Robert and Xavier Sala-i-Martin, "Convergence", Journal of Political Economy 100 (April 1992), 223-251.

Ben-David, Dan, "Equalizing exchange: Trade liberalization and convergence", Quarterly Journal of Economics 108 (August 1993), 653-679.

Berry, Albert, Francois Bourguignon and Christian Morrisson, "Changes in the World Distribution of Income Between 1950 and 1977", Economic Journal 37 (June 1983), 331-50.

Berry, Albert and John Serieux, "Riding the Elephants: World Economic Growth and Income Inequality at the end of the $20^{\text {th }}$ Century (1980-2000)", (Toronto: Centre for International Studies, University of Toronto, 2002).

Bhalla, Surgit, Imagine there's no country: Globalization and its consequences for poverty, inequality and growth (mimeo. New Delhi, India, 2001).

Bourguignon, Francois and Christian Morrisson, "Inequality Among World Citizens, 1820-1992" (forthcoming, American Economic Review, 2002/2003).

Dikhanov, Yuri and Michael Ward, "Measuring the distribution of global income" (Washington D.C.: The World Bank, 2001).

Keidel, A., "How badly do China's national accounts underestimate China's GNP?" (Rock Creek Research Inc. E-8042, 1992).

Korzeniewicz, R. and T. Moran, "World Economic Trends in the Distribution of Income, 19651992", American Journal of Sociology 102 (January 1997), 1000-1039.

Maddison, Angus, Chinese Economic Performance in the Long Run (Development Centre Studies, Paris: OECD, 1998).

Milanovic, Branco, "True World Income Distribution, 1988 and 1993: First Calculations Based on Household Surveys Alone,” Economic Journal 112 (January 2002), 51-92.

Robbins, D., "Evidence on Trade and Wages in the Developing World", OECD Development Centre Technical Paper, No. 119 (Paris: OECD, 1996).

Ren, R., China's Economic Performance in an International Perspective (Paris: OECD, 1997). 
Schultz, T. Paul, "Inequality in the distribution of personal income in the world: How is it changing and why?" Journal of Population Economics 11 (August 1998), 307-344.

UNCTAD, Trade and Development Report, 1997 (New York and Geneva: United Nations, 1997).

UNDP Human Development Report 1999 (New York and Geneva: Oxford University Press, 1998).

Wood, Adrian, North-South Trade, Employment and Inequality (Oxford and New York: Oxford University and Clarendon Press, 1994).

Wu, Harry X., "How rich is China and how fast has the economy grown? Statistical Controversies", China Economy Papers 1998/3 (Australian National University, 1998). 


\section{APPENDIX}

\section{TABLE A1}

Disaggregating likely major influences on total and per capita world output growth

\begin{tabular}{|c|c|c|c|c|c|c|c|c|c|c|}
\hline & \multicolumn{5}{|c|}{ GDP GROWTH } & \multicolumn{5}{|c|}{ PER CAPITA GDP GROWTH } \\
\hline & \multicolumn{3}{|c|}{ Measured } & \multicolumn{2}{|c|}{$\begin{array}{l}\text { Deviation } \\
\text { from actual }\end{array}$} & \multicolumn{3}{|c|}{ Measured } & \multicolumn{2}{|c|}{$\begin{array}{l}\text { Deviation } \\
\text { from actual }\end{array}$} \\
\hline & 70-80 & $80-90$ & 90-00 & $80-90$ & 90-00 & 70-80 & $80-90$ & $1990-00$ & $80-90$ & 90-00 \\
\hline Actual Growth of World Output & 3.81 & 2.86 & 2.47 & & & 1.94 & 1.16 & 1.06 & & \\
\hline $\begin{array}{l}\text { Without the per capita income growth } \\
\text { effect } \\
\text { (No change in per capita output growth from the } \\
\text { 1970s but changing population) }\end{array}$ & 3.81 & 3.64 & 3.35 & 0.78 & 0.88 & 1.94 & 1.94 & 1.94 & 0.78 & 0.88 \\
\hline $\begin{array}{l}\text { Without the population growth effect } \\
\text { (1970s population growth with actual income } \\
\text { changes) }\end{array}$ & 3.81 & 2.86 & 2.47 & 0.00 & 0.00 & 1.94 & 1.00 & 0.60 & -0.16 & -0.46 \\
\hline $\begin{array}{l}\text { Without China's Population Effect } \\
\text { (World-average population growth in China) }\end{array}$ & 3.81 & 2.86 & 2.47 & - & - & 1.94 & 1.10 & 0.90 & -0.07 & -0.16 \\
\hline $\begin{array}{l}\text { Without India's population growth effect } \\
\text { (World-average population growth in India) }\end{array}$ & 3.81 & 2.86 & 2.47 & - & - & 1.94 & 1.25 & 1.14 & 0.09 & 0.08 \\
\hline $\begin{array}{l}\text { Without China and India's population } \\
\text { growth effect } \\
\text { (World-average population growth in Chain and } \\
\text { India) } \\
\end{array}$ & 3.81 & 2.86 & 2.47 & - & - & 1.94 & 1.20 & 1.04 & 0.03 & -0.02 \\
\hline $\begin{array}{l}\text { Without China's Income Effect } \\
\text { (World-average per capita output growth in China } \\
\text { but actual population growth) }\end{array}$ & 3.81 & 2.68 & 2.12 & -0.18 & -0.35 & 1.94 & 0.98 & 0.71 & -0.18 & -0.35 \\
\hline $\begin{array}{l}\text { Without India's Income Effect } \\
\text { (World-average per capita output growth in India } \\
\text { but actual population growth) }\end{array}$ & 3.81 & 2.78 & 2.34 & -0.09 & -0.12 & 1.94 & 1.08 & 0.94 & -0.09 & -0.12 \\
\hline $\begin{array}{l}\text { Without China and India's Income Effect } \\
\text { (World-average per capita output growth in China } \\
\text { and India but actual population growth) }\end{array}$ & 3.81 & 2.58 & 1.95 & -0.28 & -0.51 & 1.94 & 0.89 & 0.55 & -0.28 & -0.51 \\
\hline $\begin{array}{l}\text { Without Japan's Income Effect } \\
\text { (World-average per capita output growth in Japan } \\
\text { but actual population growth) }\end{array}$ & 3.81 & 2.66 & 2.49 & -0.20 & 0.02 & 1.94 & 0.96 & 1.08 & -0.20 & 0.02 \\
\hline $\begin{array}{l}\text { Without Eastern Europe's Income Effect } \\
\text { (World-average per capita output growth in Eastern } \\
\text { Europe and Central Asia) }\end{array}$ & 3.81 & 2.90 & 3.02 & 0.03 & 0.55 & 1.94 & 1.20 & 1.61 & 0.03 & 0.55 \\
\hline $\begin{array}{l}\text { Without South and Central America's } \\
\text { Income Effect } \\
\text { (World-average per capita output growth in South } \\
\text { and Central America) }\end{array}$ & 3.81 & 3.02 & 2.43 & 0.16 & -0.03 & 1.94 & 1.32 & 1.03 & 0.16 & -0.03 \\
\hline $\begin{array}{l}\text { Without Africa's Income Effect } \\
\text { (World-average per capita output growth in Africa) }\end{array}$ & 3.81 & 2.93 & 2.52 & 0.06 & 0.05 & 1.94 & 1.23 & 1.11 & 0.06 & 0.05 \\
\hline
\end{tabular}




\section{TABLE A2}

Separating the effects of population and income growth on the inter-country distribution of world income when China and India are excluded

\begin{tabular}{|c|c|c|c|c|c|c|c|c|c|c|}
\hline & $\begin{array}{l}\begin{array}{l}\text { Population } \\
\text { Year }\end{array} \\
\end{array}$ & $\begin{array}{l}\text { Income } \\
\text { Year }\end{array}$ & GINI & Diff. & THEIL & Diff. & ATK. (0.5) & ATK. (1) & Diff. & ATK. (2) \\
\hline \multirow{3}{*}{ Actual } & 1980 & 1980 & 0.473 & & 0.512 & & 0.198 & 0.401 & & 0.680 \\
\hline & 1990 & 1990 & 0.510 & & 0.572 & & 0.224 & 0.436 & & 0.706 \\
\hline & 2000 & 2000 & 0.541 & & 0.634 & & 0.249 & 0.469 & & 0.730 \\
\hline \multirow{3}{*}{$\begin{array}{l}\text { No change in } \\
\text { Income }\end{array}$} & 1990 & 1980 & 0.510 & 0.000 & 0.600 & 0.028 & 0.229 & 0.451 & 0.015 & 0.722 \\
\hline & 2000 & 1990 & 0.539 & -0.002 & 0.658 & 0.024 & 0.252 & 0.482 & 0.013 & 0.746 \\
\hline & 2000 & 1980 & 0.539 & -0.002 & 0.686 & 0.052 & 0.258 & 0.497 & 0.028 & 0.758 \\
\hline \multirow{3}{*}{$\begin{array}{l}\text { Assuming } \\
\text { fixed per } \\
\text { capita income } \\
\text { differentials }\end{array}$} & 1990 & 1980 & 0.491 & -0.019 & 0.535 & -0.037 & 0.209 & 0.414 & -0.022 & 0.682 \\
\hline & 2000 & 1990 & 0.526 & -0.015 & 0.599 & -0.035 & 0.235 & 0.451 & -0.018 & 0.711 \\
\hline & 2000 & 1980 & 0.507 & -0.034 & 0.559 & -0.075 & 0.220 & 0.428 & -0.041 & 0.686 \\
\hline \multirow{3}{*}{$\begin{array}{l}\text { Assuming } \\
\text { fixed } \\
\text { population } \\
\text { differentials }\end{array}$} & 1980 & 1990 & 0.473 & -0.037 & 0.485 & -0.087 & 0.193 & 0.385 & -0.051 & 0.659 \\
\hline & 1990 & 2000 & 0.518 & -0.023 & 0.561 & -0.073 & 0.225 & 0.430 & -0.039 & 0.690 \\
\hline & 1980 & 2000 & 0.487 & -0.054 & 0.485 & -0.149 & 0.198 & 0.384 & -0.085 & 0.643 \\
\hline
\end{tabular}

TABLE A3

Simulations of the inter-country distribution of world income (1990 and 2000) without Chinese, and Indian population growth effects

\begin{tabular}{|c|c|c|c|c|c|c|c|c|c|c|}
\hline & From & To & GINI & Diff. & THEIL & Diff. & ATK. (0.5) & ATK. (1) & Diff. & ATK. (2) \\
\hline \multirow{3}{*}{ Actual } & & 1980 & 0.585 & & 0.700 & & 0.288 & 0.503 & & 0.695 \\
\hline & & 1990 & 0.578 & & 0.636 & & 0.275 & 0.471 & & 0.654 \\
\hline & & 2000 & 0.553 & & 0.559 & & 0.251 & 0.428 & & 0.623 \\
\hline \multirow{3}{*}{$\begin{array}{l}\text { China grows at } \\
\text { rest-of-the-world } \\
\text { rate }\end{array}$} & 1980 & 1990 & 0.579 & 0.002 & 0.641 & 0.005 & 0.277 & 0.473 & 0.003 & 0.656 \\
\hline & 1990 & 2000 & 0.554 & 0.001 & 0.562 & 0.003 & 0.252 & 0.430 & 0.002 & 0.622 \\
\hline & 1980 & 2000 & 0.555 & 0.002 & 0.564 & 0.005 & 0.254 & 0.431 & 0.003 & 0.621 \\
\hline \multirow{3}{*}{$\begin{array}{l}\text { India grows at } \\
\text { rest-of-the-world } \\
\text { rate }\end{array}$} & 1980 & 1990 & 0.575 & -0.002 & 0.630 & -0.006 & 0.273 & 0.467 & -0.003 & 0.653 \\
\hline & 1990 & 2000 & 0.550 & -0.003 & 0.555 & -0.004 & 0.249 & 0.426 & -0.003 & 0.622 \\
\hline & 1980 & 2000 & 0.547 & -0.005 & 0.551 & -0.009 & 0.246 & 0.423 & -0.005 & 0.621 \\
\hline \multirow{3}{*}{$\begin{array}{l}\text { Both China and } \\
\text { India grow at } \\
\text { rest-of-the-world } \\
\text { rate }\end{array}$} & 1980 & 1990 & 0.577 & -0.001 & 0.634 & -0.002 & 0.274 & 0.470 & -0.001 & 0.654 \\
\hline & 1990 & 2000 & 0.552 & -0.001 & 0.558 & -0.001 & 0.250 & 0.428 & -0.001 & 0.621 \\
\hline & 1980 & 2000 & 0.550 & -0.003 & 0.556 & -0.003 & 0.250 & 0.426 & -0.002 & 0.620 \\
\hline
\end{tabular}


TABLE A4

The World Distribution of Income Under Alternative Assumptions

\begin{tabular}{|c|c|c|c|c|c|c|}
\hline YEAR & Fixed From & GINI & THEIL & ATK. (0.5) & ATK. (1) & ATK. (2) \\
\hline \multicolumn{7}{|c|}{ ACTUAL VALUES } \\
\hline 1980 & & 0.651 & 0.891 & 0.349 & 0.590 & 0.792 \\
\hline 1990 & & 0.648 & 0.845 & 0.343 & 0.570 & 0.773 \\
\hline 2000 & & 0.639 & 0.802 & 0.332 & 0.552 & 0.763 \\
\hline \multicolumn{7}{|c|}{$\begin{array}{l}\text { MINUS THE (GLOBAL) PER CAPITA INCOME EFFECT } \\
\text { (Per capita income is fixed at } 1980 \text { or } 1990 \text { levels and population is allowed to vary) }\end{array}$} \\
\hline 1980 & & 0.651 & 0.891 & 0.349 & 0.590 & 0.792 \\
\hline 1990 & 1980 & 0.655 & 0.888 & 0.352 & 0.589 & 0.786 \\
\hline 2000 & 1990 & 0.652 & 0.847 & 0.347 & 0.571 & 0.770 \\
\hline 2000 & 1980 & 0.660 & 0.889 & 0.356 & 0.589 & 0.782 \\
\hline \multicolumn{7}{|c|}{$\begin{array}{c}\text { MINUS THE (GLOBAL) POPULATION EFFECT } \\
\text { (Population is fixed at } 1980 \text { or } 1990 \text { levels and income is allowed to vary) }\end{array}$} \\
\hline 1980 & & 0.651 & 0.891 & 0.349 & 0.590 & 0.792 \\
\hline 1990 & 1980 & 0.629 & 0.787 & 0.321 & 0.545 & 0.756 \\
\hline 2000 & 1990 & 0.625 & 0.756 & 0.317 & $\mathbf{0 . 5 3 0}$ & 0.743 \\
\hline 2000 & 1980 & 0.607 & 0.705 & 0.298 & 0.506 & 0.721 \\
\hline \multicolumn{7}{|c|}{$\begin{array}{l}\text { MINUS THE EFFECT OF CHINESE INEQUALITY } \\
\text { (Income and population are allowed to vary but inequality is fixed at the } 1980 \text { or } 1990 \text { level) }\end{array}$} \\
\hline 1980 & & 0.651 & 0.891 & 0.349 & 0.590 & 0.792 \\
\hline 1990 & 1980 & 0.647 & 0.835 & 0.341 & 0.566 & 0.768 \\
\hline 2000 & 1990 & 0.635 & 0.785 & 0.328 & 0.544 & 0.757 \\
\hline 2000 & 1980 & 0.632 & 0.776 & 0.325 & 0.540 & 0.754 \\
\hline \multicolumn{7}{|c|}{$\begin{array}{l}\text { MINUS THE EFFECT OF CHINESE INCOME GROWTH } \\
\text { (Per capita income is assumed to grow at rest-of-the-world rates but population and inequality are allowed to vary }\end{array}$} \\
\hline 1980 & & 0.651 & 0.891 & 0.349 & 0.590 & 0.792 \\
\hline 1990 & 1980 & 0.665 & 0.917 & 0.363 & 0.600 & 0.798 \\
\hline 2000 & 1990 & 0.663 & 0.884 & 0.359 & 0.587 & 0.785 \\
\hline 2000 & 1980 & 0.677 & 0.954 & 0.378 & 0.615 & 0.810 \\
\hline \multicolumn{7}{|c|}{$\begin{array}{l}\text { MINUS THE EFFECT OF CHINESE POPULATION GROWTH } \\
\text { (Population is assumed to grow at rest-of-the-world rates but income and inequality are allowed to vary) }\end{array}$} \\
\hline 1980 & & 0.651 & 0.891 & 0.349 & 0.590 & 0.792 \\
\hline 1990 & 1980 & 0.650 & 0.849 & 0.345 & 0.572 & 0.774 \\
\hline 2000 & 1990 & 0.641 & 0.805 & 0.334 & 0.553 & 0.763 \\
\hline 2000 & 1980 & 0.642 & 0.808 & 0.335 & 0.554 & 0.762 \\
\hline \multicolumn{7}{|c|}{$\begin{array}{l}\text { MINUS THE EFFECT OF CHINESE INCOME AND POPULATION } \\
\text { (Per capita income and population are assumed to grow at rest-of-the-world rates but inequality is allowed to vary }\end{array}$} \\
\hline 1980 & & 0.651 & 0.891 & 0.349 & 0.590 & 0.792 \\
\hline 1990 & 1980 & 0.666 & 0.924 & 0.365 & 0.603 & 0.800 \\
\hline 2000 & 1990 & 0.665 & 0.891 & 0.362 & 0.590 & 0.787 \\
\hline 2000 & 1980 & 0.682 & 0.972 & 0.383 & 0.622 & 0.816 \\
\hline \multicolumn{7}{|c|}{$\begin{array}{l}\text { MINUS ALL CHINESE EFFECTS } \\
\text { (Income per capita and population are assumed to grow at rest of the world rates and inequality } \\
\text { remains unchanged at } 1980 \text { or } 1990 \text { levels) }\end{array}$} \\
\hline 1980 & & 0.651 & 0.891 & 0.349 & 0.590 & 0.792 \\
\hline 1990 & 1980 & 0.665 & 0.914 & 0.364 & 0.599 & 0.793 \\
\hline 2000 & 1990 & 0.663 & 0.880 & 0.359 & 0.585 & 0.783 \\
\hline 2000 & 1980 & 0.680 & 0.956 & 0.380 & 0.616 & 0.809 \\
\hline \multicolumn{7}{|c|}{$\begin{array}{l}\text { MINUS UNITED STATES DISTRIBUTION EFFECTS } \\
\text { (US income distribution of income is assumed fixed at } 1980 \text { or } 1990 \text { levels) }\end{array}$} \\
\hline 1980 & & 0.651 & 0.891 & 0.349 & 0.590 & 0.792 \\
\hline 1990 & 1980 & 0.647 & 0.843 & 0.342 & 0.570 & 0.773 \\
\hline 2000 & 1990 & 0.640 & 0.805 & 0.333 & 0.553 & 0.763 \\
\hline 2000 & 1980 & 0.638 & 0.800 & 0.330 & 0.551 & 0.763 \\
\hline
\end{tabular}

TABLE A4 (Continued)

\begin{tabular}{|c|c|c|c|c|c|c|}
\hline YEAR & Fixed From & GINI & THEIL & ATK. (0.5) & ATK. (1) & ATK. (2) \\
\hline
\end{tabular}




\begin{tabular}{|c|c|c|c|c|c|c|}
\hline \multicolumn{7}{|c|}{$\begin{array}{c}\text { MINUS THE JAPANESE INCOME GROWTH EFFECT } \\
\text { (Japan is assumed to grow, in per capita terms, at rest-of-the-world rates) }\end{array}$} \\
\hline 1980 & & 0.651 & 0.891 & 0.349 & 0.590 & 0.792 \\
\hline 1990 & 1980 & 0.644 & 0.831 & 0.339 & 0.564 & 0.769 \\
\hline 2000 & 1990 & 0.639 & 0.802 & 0.332 & 0.552 & 0.763 \\
\hline 2000 & 1980 & 0.636 & 0.791 & 0.329 & 0.547 & 0.759 \\
\hline \multicolumn{7}{|c|}{$\begin{array}{l}\text { MINUS THE EFFECT OF WORSENING EASTERN EUROPEAN INEQUALITY } \\
\text { opean inequality is assumed fixed at } 1980 \text { or } 1990 \text { levels and income and population are allowed to vary) }\end{array}$} \\
\hline 1980 & & 0.651 & 0.891 & 0.349 & 0.590 & 0.792 \\
\hline 1990 & 1980 & 0.648 & 0.845 & 0.343 & 0.570 & 0.773 \\
\hline 2000 & 1990 & 0.638 & 0.799 & 0.331 & 0.550 & 0.762 \\
\hline 2000 & 1980 & 0.638 & 0.799 & 0.331 & 0.550 & 0.763 \\
\hline \multicolumn{7}{|c|}{$\begin{array}{c}\text { MINUS THE EFFECT OF DECLINING EASTERN EUROPEAN INCOME } \\
\text { (Eastern European per capita income is assumed to grow at rest-of-the-world rates } \\
\text { but inequality and population are allowed to vary) }\end{array}$} \\
\hline 1980 & & 0.651 & $\begin{array}{l}0.891 \\
\end{array}$ & $\begin{array}{l}0.349 \\
\end{array}$ & $\begin{array}{l}\mathbf{0 . 5 9 0} \\
\end{array}$ & 0.792 \\
\hline 1990 & 1980 & 0.648 & 0.845 & 0.343 & 0.570 & 0.773 \\
\hline 2000 & 1990 & 0.636 & 0.803 & 0.329 & 0.552 & 0.768 \\
\hline 2000 & 1980 & 0.636 & 0.803 & 0.329 & 0.552 & 0.768 \\
\hline \multicolumn{7}{|c|}{$\begin{array}{l}\text { MINUS THE EFFECT OF CHANGING INDIAN INEQUALITY } \\
\text { (Income and population are allowed to vary but inequality is fixed at the } 1980 \text { or } 1990 \text { level) }\end{array}$} \\
\hline 1980 & & 0.651 & 0.891 & 0.349 & 0.590 & 0.792 \\
\hline 1990 & 1980 & 0.649 & 0.848 & 0.343 & 0.572 & 0.776 \\
\hline 2000 & 1990 & 0.639 & 0.802 & 0.332 & 0.552 & 0.763 \\
\hline 2000 & 1980 & 0.638 & 0.794 & 0.331 & 0.548 & 0.759 \\
\hline \multicolumn{7}{|c|}{$\begin{array}{l}\text { MINUS THE EFFECT OF INDIAN INCOME GROWTH } \\
\text { (Per capita income is assumed to grow at rest-of-the-world rates but population and inequality are allowed to vary) }\end{array}$} \\
\hline 1980 & & 0.651 & 0.891 & 0.349 & 0.590 & 0.792 \\
\hline 1990 & 1980 & 0.656 & 0.876 & 0.352 & 0.584 & 0.786 \\
\hline 2000 & 1990 & 0.648 & 0.838 & 0.343 & 0.567 & $\mathbf{0 . 7 7 7}$ \\
\hline 2000 & 1980 & 0.655 & 0.871 & 0.352 & 0.582 & 0.792 \\
\hline \multicolumn{7}{|c|}{$\begin{array}{l}\text { MINUS THE EFFECT OF INDIAN POPULATION GROWTH } \\
\text { (Population is assumed to grow at rest-of-the-world rates but income and inequality are allowed to vary) }\end{array}$} \\
\hline 1980 & & 0.651 & 0.891 & 0.349 & $\mathbf{0 . 5 9 0}$ & 0.792 \\
\hline 1990 & 1980 & 0.646 & 0.838 & 0.341 & 0.567 & 0.772 \\
\hline 2000 & 1990 & 0.637 & $\begin{array}{l}\mathbf{0 . 7 9 7} \\
\end{array}$ & \begin{tabular}{|l}
0.331 \\
\end{tabular} & 0.549 & 0.762 \\
\hline 2000 & 1980 & 0.636 & 0.792 & 0.329 & 0.547 & 0.761 \\
\hline \multicolumn{7}{|c|}{$\begin{array}{l}\text { MINUS THE EFFECT OF INDIAN INCOME AND POPULATION } \\
\text { (Per capita income and population are assumed to grow at rest-of-the-world rates but inequality is allowed to vary) }\end{array}$} \\
\hline 1980 & & 0.651 & 0.891 & 0.349 & 0.590 & 0.792 \\
\hline 1990 & 1980 & 0.653 & 0.868 & 0.349 & 0.580 & 0.783 \\
\hline 2000 & 1990 & 0.644 & 0.824 & 0.338 & 0.561 & 0.772 \\
\hline 2000 & 1980 & 0.651 & 0.854 & 0.346 & 0.574 & 0.785 \\
\hline \multicolumn{7}{|c|}{$\begin{array}{l}\text { MINUS ALL INDIAN EFFECTS } \\
\text { (Per capita income, population are assumed to grow at rest of the world rates and inequality is fixed at the } 1980 \text { or } 1990 \text { levels }\end{array}$} \\
\hline 1980 & & 0.651 & 0.891 & 0.349 & 0.590 & $\begin{array}{l}0.792 \\
\end{array}$ \\
\hline 1990 & 1980 & 0.654 & 0.871 & 0.349 & 0.582 & 0.786 \\
\hline 2000 & 1990 & 0.643 & 0.814 & 0.336 & 0.557 & 0.766 \\
\hline 2000 & 1980 & 0.650 & 0.847 & 0.345 & 0.571 & 0.781 \\
\hline \multicolumn{7}{|c|}{$\begin{array}{l}\text { MINUS AFRICA'S INCOME CONTRACTION EFFECT } \\
\text { (African per capita incomes are assumed to grow at world-average rates put population growth and inequality are actual) }\end{array}$} \\
\hline 1980 & & 0.651 & 0.891 & 0.349 & 0.590 & 0.792 \\
\hline 1990 & 1980 & 0.646 & 0.828 & 0.339 & 0.563 & 0.760 \\
\hline 2000 & 1990 & 0.635 & 0.800 & 0.328 & 0.551 & $\begin{array}{l}0.768 \\
\end{array}$ \\
\hline 2000 & 1980 & 0.632 & 0.784 & 0.325 & 0.543 & 0.755 \\
\hline
\end{tabular}

TABLE A5-1

Decile Distribution of World Income 1980 and 1990: 
Actual and Simulated Values

\begin{tabular}{|c|c|c|c|c|c|c|c|}
\hline \multirow{2}{*}{ DECILE } & \multicolumn{2}{|c|}{ Actual values } & \multicolumn{5}{|c|}{ Values without the (per capita) growth effect of: } \\
\cline { 2 - 8 } & $\mathbf{1 9 8 0}$ & $\mathbf{1 9 9 0}$ & $\begin{array}{c}\text { CHINA } \\
\mathbf{1 9 9 0}\end{array}$ & $\begin{array}{c}\text { INDIA } \\
\mathbf{1 9 9 0}\end{array}$ & $\begin{array}{c}\text { AFRICA } \\
\mathbf{1 9 9 0}\end{array}$ & $\begin{array}{c}\text { S \& C } \\
\text { AMERICA } \\
\mathbf{1 9 9 0}\end{array}$ & $\begin{array}{c}\text { E. EUROPE } \\
\mathbf{1 9 9 0}\end{array}$ \\
\hline $\mathbf{1}$ & $\mathbf{0 . 6 3}$ & $\mathbf{0 . 7 1}$ & 0.63 & 0.66 & 0.76 & 0.70 & 0.71 \\
\hline $\mathbf{2}$ & $\mathbf{1 . 0 9}$ & $\mathbf{1 . 2 9}$ & 1.09 & 1.21 & 1.31 & 1.29 & 1.29 \\
\hline $\mathbf{3}$ & $\mathbf{1 . 4 5}$ & $\mathbf{1 . 6 9}$ & 1.50 & 1.58 & 1.71 & 1.67 & 1.69 \\
\hline $\mathbf{4}$ & $\mathbf{1 . 9 0}$ & $\mathbf{2 . 1 2}$ & 1.89 & 2.00 & 2.15 & 2.09 & 2.12 \\
\hline $\mathbf{5}$ & $\mathbf{2 . 5 1}$ & $\mathbf{2 . 7 5}$ & 2.52 & 2.66 & 2.85 & 2.75 & 2.75 \\
\hline $\mathbf{6}$ & $\mathbf{3 . 7 1}$ & $\mathbf{4 . 0 7}$ & 3.59 & 4.00 & 4.07 & 4.09 & 4.07 \\
\hline $\mathbf{7}$ & $\mathbf{6 . 7 3}$ & $\mathbf{6 . 2 3}$ & 5.96 & 6.15 & 6.21 & 6.35 & 6.23 \\
\hline $\mathbf{8}$ & $\mathbf{1 2 . 3 4}$ & $\mathbf{1 0 . 8 9}$ & 11.12 & 10.82 & 10.88 & 11.07 & 10.89 \\
\hline $\mathbf{9}$ & $\mathbf{2 3 . 0 6}$ & $\mathbf{2 1 . 6 1}$ & 22.06 & 21.82 & 21.53 & 21.52 & 21.61 \\
\hline $\mathbf{1 0}$ & $\mathbf{4 6 . 5 7}$ & $\mathbf{4 8 . 6 4}$ & 49.65 & 49.11 & 48.53 & 48.47 & 48.64 \\
\hline $\begin{array}{l}\text { Ratio of top } \\
\text { to bottom }\end{array}$ & $\mathbf{7 3 . 7}$ & $\mathbf{6 9 . 0}$ & $\mathbf{7 8 . 7}$ & $\mathbf{7 4 . 9}$ & $\mathbf{6 3 . 9}$ & $\mathbf{6 9 . 6}$ & $\mathbf{6 9 . 0}$ \\
\hline
\end{tabular}


TABLE A5-2

Actual and Simulated Changes in the Decile Distribution of World Income 1980-90

\begin{tabular}{|c|c|c|c|c|c|c|c|c|c|c|c|c|}
\hline \multirow[b]{3}{*}{ DECILE } & & & \multicolumn{8}{|c|}{ Change in decile distribution without the (per capita) growth effect of: } & & \\
\hline & \multicolumn{2}{|c|}{ Actual Change } & \multicolumn{2}{|c|}{ China } & \multicolumn{2}{|c|}{ India } & \multicolumn{2}{|c|}{ Africa } & \multicolumn{2}{|c|}{ S \& C America } & \multicolumn{2}{|c|}{ Eastern Europe } \\
\hline & \# & $\%$ & \# & $\%$ & \# & $\%$ & \# & $\%$ & \# & $\%$ & \# & $\%$ \\
\hline 1 & 0.07 & 11.6 & 0.00 & -0.1 & 0.02 & 3.8 & 0.13 & 20.1 & 0.06 & 10.2 & 0.07 & 11.6 \\
\hline 2 & 0.20 & 18.7 & 0.00 & 0.1 & 0.12 & 11.2 & 0.23 & 20.7 & 0.20 & 18.1 & 0.20 & 18.7 \\
\hline 3 & 0.24 & 16.3 & 0.04 & 3.0 & 0.12 & 8.5 & 0.26 & 17.8 & 0.22 & 15.1 & 0.24 & 16.3 \\
\hline 4 & 0.21 & 11.2 & -0.01 & -0.8 & 0.10 & 5.1 & 0.25 & 12.9 & 0.19 & 10.0 & 0.21 & 11.2 \\
\hline 5 & 0.24 & 9.5 & 0.01 & 0.4 & 0.15 & 6.0 & 0.33 & 13.3 & 0.24 & 9.5 & 0.24 & 9.5 \\
\hline 6 & 0.36 & 9.6 & -0.12 & -3.3 & 0.29 & 7.9 & 0.36 & 9.7 & 0.38 & 10.3 & 0.36 & 9.6 \\
\hline 7 & -0.49 & -7.3 & -0.76 & -11.3 & -0.58 & -8.6 & -0.51 & -7.7 & -0.38 & -5.7 & -0.49 & -7.3 \\
\hline 8 & -1.45 & -11.8 & -1.23 & -10.0 & -1.53 & -12.4 & -1.46 & -11.8 & -1.28 & -10.3 & -1.45 & -11.8 \\
\hline 9 & -1.45 & -6.3 & -1.01 & -4.4 & -1.25 & -5.4 & -1.53 & -6.6 & -1.54 & -6.7 & -1.45 & -6.3 \\
\hline 10 & 2.08 & 4.5 & 3.08 & 6.6 & 2.54 & 5.5 & 1.96 & 4.2 & 1.91 & 4.1 & 2.08 & 4.5 \\
\hline
\end{tabular}


TABLE A6-1

Decile Distribution of World Income 1990 and 2000: Actual and Simulated Values

\begin{tabular}{|c|r|r|r|r|r|r|}
\hline \multirow{2}{*}{ DECILE } & \multicolumn{2}{|c|}{ Actual values } & \multicolumn{3}{c|}{ Values without the growth effect of: } \\
\cline { 2 - 8 } & $\mathbf{1 9 9 0}$ & $\mathbf{2 0 0 0}$ & $\begin{array}{c}\text { CHINA } \\
\mathbf{2 0 0 0}\end{array}$ & $\begin{array}{c}\text { INDIA } \\
\mathbf{2 0 0 0}\end{array}$ & AFRICA & $\begin{array}{c}\text { E. Europe } \\
\mathbf{2 0 0 0}\end{array}$ \\
\hline $\mathbf{1}$ & $\mathbf{0 . 7 1}$ & $\mathbf{0 . 7 4}$ & 0.68 & 0.69 & 0.77 & 0.73 \\
\hline $\mathbf{2}$ & $\mathbf{1 . 2 9}$ & $\mathbf{1 . 3 2}$ & 1.13 & 1.24 & 1.33 & 1.27 \\
\hline $\mathbf{3}$ & $\mathbf{1 . 6 9}$ & $\mathbf{1 . 9 0}$ & 1.69 & 1.74 & 1.89 & 1.84 \\
\hline $\mathbf{4}$ & $\mathbf{2 . 1 2}$ & $\mathbf{2 . 4 6}$ & 2.16 & 2.28 & 2.47 & 2.40 \\
\hline $\mathbf{5}$ & $\mathbf{2 . 7 5}$ & $\mathbf{3 . 1 8}$ & 2.79 & 3.11 & 3.19 & 3.15 \\
\hline $\mathbf{6}$ & $\mathbf{4 . 0 7}$ & $\mathbf{4 . 3 9}$ & 3.79 & 4.30 & 4.40 & 4.49 \\
\hline $\mathbf{7}$ & $\mathbf{6 . 2 3}$ & $\mathbf{6 . 4 1}$ & 5.81 & 6.30 & 6.42 & 6.61 \\
\hline $\mathbf{8}$ & $\mathbf{1 0 . 8 9}$ & $\mathbf{1 0 . 1 9}$ & 10.02 & 10.09 & 10.19 & 10.87 \\
\hline $\mathbf{9}$ & $\mathbf{2 1 . 6 1}$ & $\mathbf{2 0 . 1 3}$ & 20.54 & 20.26 & 20.08 & 20.48 \\
\hline $\mathbf{1 0}$ & $\mathbf{4 8 . 6 4}$ & $\mathbf{4 9 . 2 8}$ & 51.39 & 49.99 & 49.24 & 48.16 \\
\hline $\begin{array}{l}\text { Ratio of top } \\
\text { to bottom }\end{array}$ & $\mathbf{6 9 . 0}$ & $\mathbf{6 6 . 7}$ & $\mathbf{7 5 . 1}$ & $\mathbf{7 2 . 2}$ & $\mathbf{6 4 . 0}$ & $\mathbf{6 6 . 1}$ \\
\hline
\end{tabular}


TABLE A6-2

Actual and Simulated Changes in the Decile Distribution of World Income 1990-2000

\begin{tabular}{|c|c|c|c|c|c|c|c|c|c|c|}
\hline \multirow[b]{3}{*}{ DECILE } & \multicolumn{2}{|c|}{$\begin{array}{c}\text { Actual Change } \\
1990-2000\end{array}$} & \multicolumn{8}{|c|}{ Change in decile distribution without the growth effect of: } \\
\hline & \multirow[b]{2}{*}{ \# } & \multirow[b]{2}{*}{$\%$} & \multicolumn{2}{|c|}{ China } & \multicolumn{2}{|c|}{ India } & \multicolumn{2}{|c|}{ Africa } & \multicolumn{2}{|c|}{ Eastern Europe } \\
\hline & & & $\#$ & $\%$ & $\#$ & $\%$ & $\#$ & $\%$ & $\#$ & $\%$ \\
\hline 1 & 0.03 & 4.9 & -0.02 & -3.0 & -0.01 & -1.8 & 0.06 & 9.0 & 0.02 & 3.3 \\
\hline 2 & 0.03 & 2.4 & -0.17 & -12.8 & -0.05 & -4.0 & 0.04 & 3.3 & -0.03 & -2.1 \\
\hline 3 & 0.21 & 12.3 & 0.00 & 0.0 & 0.05 & 2.9 & 0.20 & 12.1 & 0.15 & 9.0 \\
\hline 4 & 0.35 & 16.3 & 0.05 & 2.3 & 0.16 & 7.7 & 0.36 & 16.8 & 0.28 & 13.4 \\
\hline 5 & 0.43 & 15.7 & 0.04 & 1.4 & 0.35 & 12.8 & 0.44 & 16.1 & 0.40 & 14.5 \\
\hline 6 & 0.32 & 7.9 & -0.28 & -6.8 & 0.23 & 5.7 & 0.34 & 8.3 & 0.43 & 10.5 \\
\hline 7 & 0.18 & 2.8 & -0.42 & -6.8 & 0.07 & 1.1 & 0.19 & 3.0 & 0.37 & 6.0 \\
\hline 8 & -0.70 & -6.4 & -0.87 & -8.0 & -0.80 & -7.3 & -0.70 & -6.5 & -0.02 & -0.2 \\
\hline 9 & -1.48 & -6.9 & -1.07 & -5.0 & -1.35 & -6.2 & -1.53 & -7.1 & -1.13 & -5.2 \\
\hline 10 & 0.64 & 1.3 & 2.75 & 5.7 & 1.35 & 2.8 & 0.60 & 1.2 & -0.48 & -1.0 \\
\hline
\end{tabular}


TABLE A7

Medium and Large Country Poverty Rates for 1990 and 2000 when various Influences of China, India, and five large African countries

is removed

\begin{tabular}{|c|c|c|c|c|c|c|c|c|}
\hline \multirow{3}{*}{$\begin{array}{l}\text { POVERTY } \\
\text { LINES } \\
\text { (1985 ppp) } \\
\end{array}$} & \multicolumn{8}{|c|}{ WITHOUT CHINA'S EFFECT ON WORLD POVERTY } \\
\hline & \multicolumn{2}{|c|}{$\begin{array}{c}\text { CHINA'S } \\
\text { DISTRIBUTION } \\
\text { EFFECT } \\
\end{array}$} & \multicolumn{2}{|c|}{$\begin{array}{l}\text { CHINA'S INCOME } \\
\text { GROWTH EFFECT }\end{array}$} & \multicolumn{2}{|c|}{$\begin{array}{c}\text { CHINA'S } \\
\text { POPULATION } \\
\text { GROWTH EFFECT } \\
\end{array}$} & \multicolumn{2}{|c|}{$\begin{array}{c}\text { CHINA'S OVERALL } \\
\text { EFFECT }\end{array}$} \\
\hline & 1990 & 2000 & 1990 & 2000 & 1990 & 2000 & 1990 & 2000 \\
\hline$<\mathbf{5 0 0}$ & 13.9 & 10.9 & 20.5 & 16.0 & 15.2 & 12.1 & 19.9 & 14.1 \\
\hline$<\mathbf{1 0 0 0}$ & 41.0 & 26.6 & 46.9 & 34.9 & 44.3 & 29.1 & 48.9 & 35.5 \\
\hline \multirow[t]{4}{*}{$<\mathbf{1 5 0 0}$} & 56.1 & 44.2 & 58.1 & 51.2 & 54.1 & 46.1 & 58.8 & 50.6 \\
\hline & \multicolumn{8}{|c|}{ WITHOUT INDIA'S EFFECT ON WORLD POVERTY } \\
\hline & \multicolumn{2}{|c|}{$\begin{array}{c}\text { INDIA'S } \\
\text { DISTRIBUTION } \\
\text { EFFECT } \\
\end{array}$} & \multicolumn{2}{|c|}{$\begin{array}{l}\text { INDIA'S INCOME } \\
\text { GROWTH EFFECT }\end{array}$} & \multicolumn{2}{|c|}{$\begin{array}{l}\text { INDIA'S POPULATION } \\
\text { GROWTH EFFECT }\end{array}$} & \multicolumn{2}{|c|}{$\begin{array}{c}\text { INDIA'S OVERALL } \\
\text { EFFECT }\end{array}$} \\
\hline & 1990 & 2000 & 1990 & 2000 & 1990 & 2000 & 1990 & 2000 \\
\hline$<\mathbf{5 0 0}$ & 15.1 & 10.1 & 19.5 & 12.7 & 14.1 & 11.1 & 18.5 & 11.6 \\
\hline$<\mathbf{1 0 0 0}$ & 43.1 & 26.4 & 46.6 & 32.6 & 43.1 & 28.0 & 46.1 & 30.6 \\
\hline \multirow[t]{4}{*}{$<\mathbf{1 5 0 0}$} & 54.1 & 44.3 & 55.6 & 46.9 & 53.6 & 44.8 & 55.6 & 46.4 \\
\hline & \multicolumn{8}{|c|}{ WITHOUT AFRICA'S EFFECT ON WORLD POVERTY } \\
\hline & \multicolumn{2}{|c|}{$\begin{array}{c}\text { AFRICA'S } \\
\text { DISTRIBUTION } \\
\text { EFFECT } \\
\end{array}$} & \multicolumn{2}{|c|}{$\begin{array}{l}\text { AFRICA'S INCOME } \\
\text { GROWTH EFFECT }\end{array}$} & \multicolumn{2}{|c|}{$\begin{array}{c}\text { AFRICA'S } \\
\text { POPULATION } \\
\text { GROWTH EFFECT } \\
\end{array}$} & \multicolumn{2}{|c|}{$\begin{array}{l}\text { AFRICA'S OVERALL } \\
\text { EFFECT }\end{array}$} \\
\hline & 1990 & 2000 & 1990 & 2000 & 1990 & 2000 & 1990 & 2000 \\
\hline$<500$ & 14.6 & 11.6 & 14.6 & 11.5 & 14.6 & 11.3 & 14.1 & 11.2 \\
\hline$<1000$ & 43.6 & 28.5 & 43.4 & 28.5 & 43.4 & 28.5 & 43.4 & 28.5 \\
\hline$<1500$ & 54.3 & 45.2 & 53.7 & 44.8 & 53.3 & 44.8 & 53.3 & 44.6 \\
\hline
\end{tabular}

Note: $\quad$ The large African countries are Ethiopia, Kenya, Nigeria, South Africa and Tanzania. Though the Congo would also have qualified as a large country, no distribution data was available for that country.

The poverty rates of medium and large countries are extrapolated to the whole world by assuming that poverty rates in small countries are roughly the same as that of medium and large countries. Thus, the rates recorded above are relative to that reported in Table 6 in the text. 


\section{CESifo Working Paper Series}

(for full list see www.cesifo.de)

775 Steven Brakman, Harry Garretsen, and Charles van Marrewijk, Locational Competition and Agglomeration: The Role of Government Spending, September 2002

776 Anke S. Kessler and Christoph Lülfesmann, The Theory of Human Capital Revisited: On the Interaction of General and Specific Investments, September 2002

777 Kjell Erik Lommerud, Frode Meland and Lars Sørgard, Unionized Oligopoly, Trade Liberalization and Location Choice, September 2002

778 Antonio Merlo and François Ortalo-Magné, Bargaining over Residential Real Estate: Evidence from England, September 2002

$779 \mathrm{Yu}-\mathrm{Fu}$ Chen and Michael Funke, Exchange Rate Uncertainty and Labour Market Adjustment under Fixed and Flexible Exchange Rates, September 2002

780 Michael S. Michael, International Migration, Income Taxes and Transfers: A Welfare Analysis, September 2002

781 Clemens Fuest and Alfons Weichenrieder, Tax Competition and Profit Shifting: On the Relationship between Personal and Corporate Tax Rates, October 2002

782 Jan Bouckaert and Hans Degryse, Softening Competition by Enhancing Entry: An Example from the Banking Industry, October 2002

783 Johann K. Brunner and Susanne Pech, Adverse Selection in the Annuity Market with Sequential and Simultaneous Insurance Demand, October 2002

784 Gregory D. Hess and Eduard Pelz, The Economic Welfare Cost of Conflict: An Empirical Assessment, October 2002

785 Jan Erik Askildsen, Uwe Jirjahn, and Stephen C. Smith, Works Councils and Environmental Investment: Theory and Evidence from German Panel Data, October 2002

786 Geir H. Bjønnes, Dagfinn Rime, and Haakon O. Aa. Solheim, Volume and Volatility in the FX-Market: Does it matter who you are?, October 2002

787 John Evans and John Fingleton, Entry Regulation and the Influence of an Incumbent Special Interest Group, October 2002

788 Wolfgang Ochel, International Comparisons and Transfer of Labour Market Institutions, October 2002

789 B. Gabriela Mundaca, Moral Hazard Effects of Bailing out under Asymmetric Information, October 2002 
790 Gene M. Grossman and Edwin L.-C. Lai, International Protection of Intellectual Property, October 2002

791 John Hassler, José V. Rodriguez Mora, Kjetil Storesletten, and Fabrizio Zilibotti, A Positive Theory of Geographic Mobility and Social Insurance, October 2002

792 Paul De Grauwe and Marianna Grimaldi, The Exchange Rate in a Model with Heterogeneous Agents and Transactions Costs, October 2002

793 Guido Friebel and Mariassunta Giannetti, Fighting for Talent: Risk-shifting, Corporate Volatility, and Organizational Change, October 2002

794 Jan Erik Askildsen, Badi H. Baltagi, and Tor Helge Holmås, Will Increased Wages Reduce Shortage of Nurses? A Panel Data Analysis of Nurses' Labour Supply, October 2002

795 Marko Köthenbürger and Panu Poutvaara, Social Security Reform and Intergenerational Trade: Is there Scope for a Pareto-Improvement?, October 2002

796 Paul De Grauwe and Laura Rinaldi, A Model of the Card Payment System and the Interchange Fee, October 2002

797 Volker Böhm and Tomoo Kikuchi, Dynamics of Endogenous Business Cycles and Exchange Rate Volatility, October 2002

798 Mariam Camarero, Javier Ordóñez, and Cecilio Tamarit, The Euro-Dollar Exchange Rate: Is it Fundamental?, October 2002

799 Misa Tanaka, How Do Bank Capital and Capital Adequacy Regulation Affect the Monetary Transmission Mechanism?, October 2002

800 Jörg Baten and Andrea Wagner, Autarchy, Market Disintegration, and Health: The Mortality and Nutritional Crisis in Nazi Germany, 1933-1937, October 2002

801 Saku Aura, Uncommitted Couples: Some Efficiency and Policy Implications of Marital Bargaining, October 2002

802 Wolfram F. Richter, Delaying Integration of Immigrant Labor for the Purpose of Taxation, October 2002

803 Gil S. Epstein and Shmuel Nitzan, The Politics of Randomness, October 2002

804 John Hassler and José V. Rodriguez Mora, Should UI Benefits Really Fall over Time?, October 2002

805 Friedrich Breyer and Stefan Felder, The Dead-anyway Effect Revis(it)ed, October 2002

806 Assar Lindbeck and Solveig Wikström, E-exchange and the Boundary between Households and Organizations, November 2002 
807 Dieter Bös, Contests Among Bureaucrats, November 2002

808 Steven Brakman, Harry Garretsen, and Marc Schramm, The Strategic Bombing of German Cities during World War II and its Impact on City Growth, November 2002

809 Florian Englmaier and Achim Wambach, Contracts and Inequity Aversion, November 2002

810 Sarbajit Sengupta, Delegating Recruitment under Asymmetric Information, December 2002

811 Rajshri Jayaraman, On the Partial Public Provision of a Private Good, December 2002

812 Stéphanie Stolz, Banking Supervision in Integrated Financial Markets: Implications for the EU, December 2002

813 Christian Keuschnigg, Taxation of a Venture Capitalist with a Portfolio of Firms, December 2002

814 Inés Macho-Stadler and David Pérez-Castrillo, Settlement in Tax Evasion Prosecution, December 2002

815 Rainer Niemann and Dirk Simons, Costs, Benefits, and Tax-induced Distortions of Stock Option Plans, December 2002

816 Jan-Egbert Sturm and Barry Williams, Deregulation, Entry of Foreign Banks and Bank Efficiency in Australia, December 2002

817 V. Anton Muscatelli, Patrizio Tirelli, and Carmine Trecroci, Monetary and Fiscal Policy Interactions over the Cycle: Some Empirical Evidence, December 2002

818 Claude Hillinger, A General Theory of Price and Quantity Aggregation and Welfare Measurement, December 2002

819 Erkki Koskela and Ronnie Schöb, Optimal Capital Taxation in Economies with Unionised and Competitive Labour Markets, December 2002

820 Sheilagh Ogilvie, Guilds, Efficiency, and Social Capital: Evidence from German ProtoIndustry, December 2002

821 Hans Gersbach and Verena Liessem, Financing Democracy, December 2002

822 Costas Hadjiyiannis, Panos Hatzipanayotou, and Michael S. Michael, Optimal Tax Policies with Private-Public Clean-Up, Cross-Border Pollution and Capital Mobility, December 2002

823 François Ortalo-Magné and Sven Rady, Homeownership: Low Household Mobility, Volatile Housing Prices, High Income Dispersion, December 2002

824 Syed M. Ahsan and Panagiotis Tsigaris, Measuring the Social Discount Rate under Uncertainty: A Methodology and Application, December 2002 
825 Kai A. Konrad, Altruism and Envy in Contests: An Evolutionarily Stable Symbiosis, December 2002

826 Robert S. Chirinko and Huntley Schaller, A Revealed Preference Approach to Understanding Corporate Governance Problems: Evidence from Canada, December 2002

827 Geir B. Asheim, Green National Accounting for Welfare and Sustainability: A Taxonomy of Assumptions and Results, December 2002

828 Andrea Gebauer, Chang Woon Nam, and Rüdiger Parsche, Lessons of the 1999 Abolition of Intra-EU Duty Free Sales for Eastern European EU Candidates, December 2002

829 Giacomo Corneo, Work and Television, December 2002

830 Vivek H. Dehejia and Yiagadeesen Samy, Trade and Labour Standards - Theory, New Empirical Evidence, and Policy Implications, December 2002

831 Geir B. Asheim and Wolfgang Buchholz, A General Approach to Welfare Measurement through National Income Accounting, December 2002

832 Aaron Tornell and Frank Westermann, The Credit Channel in Middle Income Countries, January 2003

833 Gebhard Flaig, Time Series Properties of the German Monthly Production Index, January 2003

834 Campbell Leith and Jim Malley, Estimated Open Economy New Keynesian Phillips Curves for the G7, January 2003

835 Burkhard Heer and Bernd Süssmuth, Inflation and Wealth Distribution, January 2003

836 Erkki Koskela and Leopold von Thadden, Optimal Factor Taxation under Wage Bargaining - A Dynamic Perspective, January 2003

837 Carola Grün and Stephan Klasen, Growth, Income Distribution, and Well-Being: Comparisons across Space and Time, January 2003

838 Robert S. Chirinko and Ulf von Kalckreuth, On the German Monetary Transmission Mechanism: Interest Rate and Credit Channels for Investment Spending, January 2003

839 Sascha O. Becker, Andrea Ichino, and Giovanni Peri, How Large is the "Brain Drain" from Italy?", January 2003

840 Albert Berry and John Serieux, All About the Giants: Probing the Influences on Growth and Income Inequality at the End of the $20^{\text {th }}$ Century, January 2003 